\title{
Constitutional and Legal Problems \\ of Anti-Extremist Legislation in Russia: \\ Drawbacks of Legislative Regulation
}

\author{
Andrey A. Kondrashev* \\ Siberian Federal University \\ 79 Svobodny, Krasnoyarsk, 660041, Russia
}

Received 12.04.2015, received in revised form 14.06.2015, accepted 18.08.2015

The paper criticises doctrinal approaches to the definition of extremism, as well as the legal definition of extremist activities; the author identifies gaps and contradictions in legal regulation of responsibility for extremist crimes.

Keywords: extremism, extremist activity, hate crimes, violations of constitutional rights and freedom of citizens in enforcement of anti-extremist legislation.

DOI: 10.17516/1997-1370-2015-8-10-2092-2099.

Research area: law.

In 2001 Russian law got a relatively new legal term defined by most authors as "extremism". In the scientific literature, the term "extremism" is defined as a rule in the same way: "Extremism (French - extremisme, from Latin extremus extreme) is a commitment to extreme views, ideas and actions aimed at achieving the goals of radically oriented social institutions, small groups and individuals"1. According to the dictionary of the Russian language edited by S.I. Ozhegov, extremism is the commitment to extreme views and actions in politics and ideology ${ }^{2}$.

In fact, until 2001 the word extremism in the Russian language (both in common usage and in the special legal usage) had been used as an analogue of radicalism, as going beyond conventional norms and rules in various spheres of human life (ideology, politics, culture, etc.). Attempts to use the term without legal implications were suppressed by the Constitutional Court of the Russian Federation, which while testing the constitutionality of the Presidential Decree dated 28 October 1992 "On measures for the protection of the constitutional system of the Russian Federation"3, stated: "The words "extremist elements' in this paragraph of the Decree have no legal value, as the term has no specific legal content, while ambiguities may lead to a violation of the constitutional rights of citizens during the enforcement of the Decree"4.

Paragraph 3 Part 1 Article 1 of Shanghai Convention of 15 June 2001 (on Combating Terrorism, Separatism and Extremism), ratified by the Russian Federation, defines extremism as

(C) Siberian Federal University. All rights reserved

* Corresponding author E-mail address: legis75@mail.ru 
an act which is aimed at the seizure or retention of power via violent methods; changes in the constitutional order by force, as well as forcible encroachment upon public security, including the organization of illegal armed formations and participation in them. Extremism is treated as criminal offense in accordance with national legislation ${ }^{5}$.

And after Russia ratified the Convention ${ }^{6}$, it adopted the Federal Law № 114-FZ “On countering extremist activities", which gives a definition of extremist activity, enlisting 13 kinds of them. This law supplemented the Penal Code with articles providing description of punishment for organizing extremist communities, the activities of an extremist organization, and funding such activities.

On July 8, 2002, at the "round table" dedicated to the Federal Law "On countering extremist activities" representatives of 15 human rights NGOs addressed the President of the Russian Federation and the Federation Council with a request to reject the adoption of this law. As V. Garbisov, the head of the NGO "For Civil Rights", told, the law "On countering extremist activity" contradicts Articles 13, 14, 17, 18, 28 and 29 of the Constitution of the Russian Federation and a number of international instruments on the rights and freedoms of man and citizen. According to the author of the appeal Doctor of Juridical Sciences, human rights activist Mikhail Kuznetsov, "the problem of extremism in Russia today is contrived, and these laws are directed not at stabilizing the domestic situation, but at infringement of the rights and freedoms of Russian citizens". And, according to Lev Levinson, an expert of the Institute of Human Rights, the concept of "extremist activity" defined by the law, "describes a variety of criminal offenses already set out in the Criminal Code, so this situation in itself is a "pointless duplication of the Criminal Code"?.
It should be noted that currently this law with numerous amendments has become even more "pointless", because in addition to the existing formulations of the Criminal Code, it lists a variety of prohibited acts, which are not fixed in the law as crimes or administrative offenses.

The Russian science studying criminal law still does not have a more or less distinct and common understanding of what the proverbial "extremism" represents. Moreover, many of these definitions are just estimates and do not comply with the legal terminology, they rather belong to political science rhetoric or philosophical tradition.

Thus, according to A.G.Zaluzhny, extremism can refer to "actions, as well as publicly expressed views and intentions of pursuing violation or disrespect to the statutory rights and freedoms of citizens, common and equitable standards of morality, public order and the general welfare in a democratic society, provided that the legal significance of these actions is proved by court"8. In other words, from the point of view of this approach, even criticism of the government can be considered as extremism!

And in terms of V.I. Vlasov, "extremism is a negative phenomenon that comes from extreme views, adherence to extreme measures, which manifests itself in the activities of radical entities for planning, organization, preparation and commission of prohibited by law socially dangerous acts or immoral actions having political, nationalistic aims, or made because of racial or religious feud (hatred)"'. In fact, the author of this definition identifies extremism with radicalism and immoral actions, which is obviously methodologically wrong.

Some authors believe that violence is not inherent in extremism. So, V.V. Revina observes: "Violence is not a mandatory criterion for classifying certain actions as extreme. Concerning a form of expression there can be 
violent and non-violent extremism. At the same time in determining the presence or absence of signs of extremism one should take into account such criteria as its illegal character, which means that this activity is prohibited by law precisely as extreme one and that a parson making extreme actions thus violates the legal prohibition, therefore he/she should meet, as noted earlier, criminal or administrative liability"10. Again, the author is not right in assuming that "extremism" relates to any criticism of the authorities, even shocking one; in fact it leads to a direct infringement of the constitutional freedom of thought and speech.

V.V. Ustinov in his writings on terrorism characterized extremism as "aggressive behavior (attitude) of an individual, the most significant external manifestations of which are intolerance to opponents, who are oriented to generally accepted norm in society; the tendency to extreme (forcible) solutions to the problem; the failure of consensus ... the individual's rights and person's intrinsic value" $"$.

I find far more appealing the position expressed by the P.A. Danilov: "extremism are illegal activities of individuals, officials ... based on adherence to extreme views and is accompanied by public violence aimed at belittling and denial of the constitutional principles of the rights, freedoms and legitimate interests of the person, individual, society and state" ${ }^{\prime 2}$. But it should be noted that despite the fact that the author of this definition is absolutely correct in emphasizing the need to recognize only violent actions as extremism, we still cannot see a clear understanding of what extremism represents in his approach.

In our opinion, the development of a common definition of extremism is simply impossible, as the concept is originally polysemous, purely judgmental in nature and most importantly does not have any distinct and clear, internationally recognized standards of law enforcement.
For this reason, it can be supposed that any attempts to "develop the most capacious definition of 'extremism', which would fully cover all the aspects of the essential nature of this negative phenomenon, which would in its turn allow any entity of public relations to regulate their behavior in accordance with it" ${ }^{\prime 13}$ are doomed to failure...

Why does this concept, as we see it, having been included in the Russian legislation 14 years ago, result in massive violations of citizens' constitutional rights and why should it be removed from the practice of law? Let us try to give some arguments both from the point of constitutional law and taking into account the criminal and legal specifics of its use in Russia.

1. The list of so-called constituting the extremist activity acts is full of either the references to specific articles of the Criminal Code (many of which are already in the Criminal Code) or indications of the specific actions that are prohibited by law, but not criminalized.

Actually most of the regulations of the Criminal Code, referring to extremist ones, contain an indication of the corresponding motive: political, ideological, racial, ethnic or religious hatred or feud (or any motive of such kind) against any social group. For example Art. 105 (murder), Art. 111 (intentional infliction of a grave injury), Art. 115 (intentional infliction of light injury), Art. 116 (battery), Art. 117 (torture), 119 (threat of murder or infliction of grave injury), and others. Only 4 articles of the Criminal Code are extreme in their pure form and name; these are Art. 280 "Public calls for extremist activities", Art. 282.1. "The organization of an extremist community", Art. 282.2. "The organization of an extremist organization" and Art. 282.3. "Financing of extremist activity". So actually extremism, in terms of nature of an action, is a crime committed with a special motive, based on hatred and feud on grounds of race, ideology, 
ethnicity, religion or belonging to a social group. In fact, all these crimes had been in our Criminal Code even until 2002. If to mention these 4 articles of the Criminal Code, which have "extremism" in their titles - Art. 280, 282.1., 282.2. 282.3, their practical usage is extremely difficult, and unlikely to be useful, since many of the elements are already in Art. 35 and Art. 210 of the Criminal Code. These articles define the concept of a criminal organization (community). In terms of comparison between the relevant rules of the Criminal Code, the application of these articles is very difficult, because the legal and technical standards of their usage are not adequately integrated in the Criminal Code.

In general, if one considers all of these articles, there are a lot of questions about the possibility of their application to political opponents of the current government or religious organizations different from the traditional Russian confessions. In most countries, the criminal law lacks such issues. I cannot but say that foreign criminal legislation does not establish criminal responsibility for extremism, because this wording seems legally incorrect because of the absence of the word "extremism" in the foreign legislation. For example, in the United States, crimes motivated by racial, ethnic, religious and any other (for example, untraditional sexual orientation) prejudices are called hate crimes ${ }^{14}$. Hate crimes or, as they can be also called, crimes of bias (prejudices), are acts of violence directed against a specific person or group of people, simply because the target of these actions is the personal characteristics of the person depending on his/her racial, ethnic, religious belonging and also depending on the gender characteristics.

In the United States, responsibility for such crimes is only possible in case of actions, while words and texts, containing signs of feud and hatred, are not subject to criminal-legal assessment, as this may lead to a breach of the constitutional freedom of speech.

\section{Another highly controversial aspect} of the Act is reference of public justification of terrorism and other terrorist activity to illegal activities, recognized as extremism. The scientific papers have an opinion that "terrorism is the most dangerous form of extremism"15, but the Criminal Code articles do not allow to conclude about such a relationship between terrorism and extremism. Whereas the Criminal Code (Art. 205, 205.1, 205.2) does not list such possible motives as of political, ideological, racial, ethnic or religious hatred or feud, or hatred or feud against any social group ${ }^{16}$. Moreover, terrorism implies a very specific purpose of committing a criminal act, which is the impact on the authorities' or international organizations' decisions (Part. 1, Art. 205 of the Criminal Code). Furthermore, the list of criminal assaults, facilitating or financing of which is an offense, does not include extremist crimes. And finally, Art. 3 of the Federal Law dated March 6, 2006 N 35-FZ "On countering terrorism $^{17}$ in its description of "terrorism", "terrorist activity" and "terrorist act" concepts does not have any indication of extremism or hate motive of racial, national, political, ideological or social kind.

It is also a problem to understand the "justification" of terrorism; this term has no distinct legal standard of use.

3. Some criminal offenses are classified as extreme in general without any clear reason. For example, Article 1 of the Federal Law № 114-FZ includes among such acts "obstruction of the exercise of voting rights or the work of electoral commissions" (Art. 141 of the Criminal Code). It is absolutely unclear where a motive of hatred or feud there is? For what reason is the crime against the constitutional rights related to extreme one? It is absolutely incomprehensible from the analysis of legal norms. 


\section{Some of the prohibited acts enlisted in} the law are not linked to the relevant criminal or administrative offenses. These are only a few signs of the subjective side of completely different criminal offences (e.g., Subparagraph 7 Paragraph 1, Art. 1 of the Federal Law № 114-FZ defines this act as "impeding the legitimate activities of government agencies, local governments, electoral commissions, public and religious associations or other organizations and having violence or threat of violence"). At the same time in the Criminal Code, a sign of the subjective aspect of the crime is aiming at journalists (Art. 144), judges, prosecutors and investigators as people involved in the law enforcement (Art. 295 of the Criminal Code) or at the police (Art. 317 of the Criminal Code). How this act in general can be correlated with the corresponding implications and considered to be extreme?

5. Individual acts in general are not considered criminal in the Criminal Code or are not recognized as administrative offenses by the Administrative Code, but nevertheless are defined as extreme. Thus, according to Subparagraph 11 Paragraph 1, Art. 1 of the Federal Law № 114-FZ an extremist act is "public and known to be false accusation of a public servant of the Russian Federation or a public servant in some regions of the Russian Federation of commitment during the service term any acts stated in this Article and constituting a crime". It is generally beyond the scope of law! In other words, a person, who in the course of criticizing the activities of a politician (officer) stretches the point and suggests that this officer is involved in the commission of certain offenses, would be called an extremist! ${ }^{18}$. This is common defamation that may concern public figures (including politicians and government officials), and the responsibility for it, if there is any in the civilized countries, is within the framework of civil law. Such an approach of Russian legislator is quite contrary to the established practice of the ECtHR, according to which officials and active state officers have to withstand greater criticism than ordinary people ${ }^{19}$. It also does not correspond to the principle of equality of everybody in front of the law and the court; otherwise the law protects only the official, but not an ordinary person, which is generally unacceptable in a democratic society!

\section{The uncertainty in the description} of the objective aspect of relevant extremist situations. In particular, the pre-existing Article 280 of the Criminal Code, "Public appeals for a forcible change of the constitutional system of the Russian Federation" was renamed as the "Public calls for extremist activities", while previously the disposition of this article has set responsibility for the very specific actions (namely a forcible change of the constitutional system, a forcible seizure or retention of power), now it sets responsibility for "public incitement" to implement some kind of "extremist activity", which, given the obvious uncertainty of this violating the principle of legal certainty concept, enables an unusually broad and unjustified use of criminal repression against political opponents of the current government. Moreover, if previously the necessary element of the crime to be punished was violence, now everything is at the mercy of the experts and investigators who can see the criminal situation even in completely neutral comments But the most ridiculous is the introduced in $2014^{20}$ by legislators "equalization" of comment, repost, and even the so-called "likes" on the Internet to the media, which according to Part 2 Arts. 280 entails severe criminal responsibility of citizens. In practice, this has led to, that using this article law enforcement agencies began to prosecute scientists, opposition activists and ordinary citizens who expressed careless valuation of certain events and actions of certain individuals ${ }^{21}$.

In addition, courts began to recognize as extremist some slogans that are associated with 
belonging to a particular national group (to the Russians), but do not limit or diminish the equality and specifics of other ethnic groups ${ }^{22}$.

International organizations have repeatedly drawn the attention of the Russian authorities to the inadmissibility of the use of the law № 114FZ and the relevant regulations of the Criminal Code, which lead to violations of citizens' constitutional rights. Back in 2009 the United Nations Human Rights Committee analyzed the sixth periodic report of the Russian Federation (CCPR/C/SR.2681) and expressed regrets that the definition of extremist activity in the Law on countering extremist activity remains vague, allowing for arbitrariness in its application, and also because due to the amendments made to the Act in 2006 some forms of defamation of public officials are now considered as acts of extremism. In addition, the Committee expressed concern that some of the provisions of Article 1 of the Law on countering extremist activity include measures not provided for in the Criminal Code. The Committee recommended reconsidering the Law on countering extremist activity, in order to make the definition of extremist activities more accurate, and thereby to exclude any possibility of arbitrary application, and also to consider repealing the amendment of 2006. Furthermore, in determining whether any written material is extremist literature, the State party should take all measures to ensure independence of experts, who would determine the courts' final decisions, and guarantee the right of the defendant to counter-examination involving an alternative $\operatorname{expert}^{23}$.

In addition, one more federal law came into force on February 1, 2014²4. It allows on the basis of the requirements of the leaders of the Prosecutor General Office sent to Roskomnadzor (Federal Supervision Agency for Information Technologies and Communications) restricting access to sites containing illicit information.
Restriction is implemented by non-judicial means and so far illicit information has been removed from more than 100 sites $^{25}$.

Law enforcement agencies are increasingly carrying out "work" for the recognition of some materials as extremist in the court. By May 1, 2015, the federal list already included 2812 sites $^{26}$ (in 2012 the number was only 1.5 thousand $)^{27}$. If one turns to the federal list of extremist materials in it, along with materials containing calls to, say, the "abrupt" murder of individual representatives of certain national and racial groups, and so on, one might find religious literature and literature on religion studies, various historical documents, and even independent trade unions' leaflets containing calls to the struggle for labor rights.

In conclusion, I would like to note that the author does not favor decriminalization of all actions falling under the signs of extremism. It seems that until 2002 Russian legislation coped with counteraction to crimes committed on the grounds of hatred and feud. Nevertheless, modern anti-extremist legislation and its practical application limit not just political activities, but also research in the field of sociology, political science, history, law, and so on. Moreover, analyzing the practice of its application in Russia one must state that one of the objectives of legislation's introduction, as human rights activists had warned, was the persecution of the political opposition, broad restriction of basic constitutional rights and freedom of citizens (freedom of speech, conscience, assembly and association). Law enforcement authorities using the so-called "extremist articles" demonstrate the massive intervention in the private lives of citizens, enlist opposition activists in various police databases and in fact form the police regime in the country under the pretext of fighting extremism. 
Great Soviet Encyclopedia. $3^{\text {rd }}$ ed. M., 1978. Vol.30. P.19.

See in detail Ozhegov, S.I., Shvedova, N.Iu. Dictionary of the Russian Language. M., 1994. P. 896.

Presidential Decree dated 28 October .1992 N 1308 (ed. 13 January 1993) "On measures for the protection of the constitutional system of the Russian Federation". Collection of Acts of the President and the Government of the Russian Federation", 02.11.1992, N 18, Art. 1458.

4 Decision of the Constitutional Court of the Russian Federation dated 12.02.1993 N 3-П "On verification the constitutionality of the Presidential Decree of October 28, 1992 N 1308 "On measures for the protection of the constitutional system of the Russian Federation". Collection of Acts of the President and the Government of the Russian Federation", 01.03.1993, N 9, Art. 825.

5 "Shanghai Convention on Combating Terrorism, Separatism and Extremism" (signed in Shanghai on June 15, 2001). Collection of Laws of the Russian Federation. October 13, 2003, N 41. Art. 3947.

6 It was signed by states, which as the majority of civilized countries consider, have created political regimes that have all the attributes of authoritarian or totalitarian states. There is no international act, apart from the mentioned above, which would identify the characteristics of the extremism phenomenon.

7 Stavitskaia, A. Law "On countering extremist activity". Legal commentary. Available at: http://studies.agentura. ru/tr/ presscoverage/extremist/

Zaluzhny, A.G. Legal problems of church-state relationships in modern Russia. M, 2004. P. 195 - 196.

Vlasov, V.I. Extremism: tnature, types, prevention: Textbook. M., 2003. P. 8.

10 Revina, V.V. K voprosu o poniatii ekstremizma [On the concept of extremism]. Rossiiskii sledovatel' (Russian investigator). 2009. N 13. Pp. $36-40$.

11 Ustinov, V.V. Obviniaetsia terrorizm [Terrorism is accused]. M., 2002. P. 16.

12 Danilov, P.A. Zashchita prav, svobod i zakonnykh interesov lichnosti pri protivodeistvii ekstremizmu [Protection of the rights, freedoms and lawful interests of individuals at countering extremism]. St. Petersburg, 2011. P. 83.

13 Golubykh, N.V., Legotin, M.P. O sushchnosti poniatiia "ekstremizm" [On the essence of the concept of "extremism"]. Advocat (Lawyer). 2013. N 6. P. 31.

14 See in detail: Larry J. Siegel. Criminology. Thomson Learning, 2006.

15 Cited by Kochoi, S.M. Ekstremizm: problem protivodeistviia [Extremism: problems of counteraction]. Sovremennye raznovidnosti rossiiskoi i mirovoi prestupnosti: sostoianie, tendentsii, vozmozhnosti i perspektivy protivodeistviia (Modern varieties of Russian and world crime: status, trends, opportunities and prospects of counteraction). Saratov, Saratov Center for the study of organized crime and corruption: Satellite, 2005. P. 288.

16 Iudicheva, S.A. Aktual'nye problem iuridicheskogo analiza sostavov prestuplenii organizatsii ekstremistskogo soobshchestva i uchastiia $\mathrm{v}$ nem [Topical problems of legal analysis of crimes of an extremist community organization and participation in it]. Novyi iuridicheskii zhurnal (New law journal). 2013. N 2. P. 190.

17 The Criminal Code defines an extremist community as an organized group of people, that gives rise to certain inconsistencies in the terminology, "in the framework of the article the concepts of an "organized group" and "criminal community" are mixed. The scientific literature has indications of inconsistency of Art. 282.1 with the other provisions of general and specific parts of the Criminal Code; excessive references to corresponding criminal law and its excessive and different attributes, so understanding its immediate purpose is difficult even for experts of criminal law, not to mention the practical workers. This situation makes the specified regulation "dead" in its origin, which casts doubt on its continued application. See in detail: Khlebushkin, A.G. The criminal extremism: concept, types, problems of criminalization and penalization. Abstract of Thesis of Candidate of Juridical Sciences. Saratov, 2007. P. 9; Agapov, P.V., Khlebushkin, A.G. The organization of an extremist community: a critical analysis of the article 282.1 of the Criminal Code of the Russian Federation. Crime and corruption: contemporary Russian realities. Saratov, Saratov center for the study of organized crime and corruption, 2003. P. 401. As noted in the scientific literature, an organized group, in practice, is almost impossible to distinguish from a criminal organization, as well as from a collusive group, in connection with which the recognition of a formation as an extremist community is very problematic. See in detail: Ivanov, A.V. The nuances of criminal law regulating the extreme activities of as a variety of group crimes. State and law. 2003. N 5. P. 47.

18 Sultanov, A.R. Protection of freedom of conscience and beliefs through the prism of the European Court of Human Rights. M., Statut, 2013. P. 420.

19 Lingens v. Austria, July 8, 1986, complaint N 9815/82, point 42. The effect of this principle was subsequently extended to the current officers and government officials: Thoma v. Luxembourg, March 29, 2001, complaint N 38432/97, point 47.

20 Federal Law dated June 28, 2014 N 179-FZ "On amendments to certain legislative acts of the Russian Federation". Collection of the legislation of the Russian Federation, June 30, 2014, N 26 (Part I), Art. 3385.

21 E.g., V. Filippov from Kazan liked the photo of E. Norton, who starred in the film "American History X". The photo had a swastika on the chest of the actor, and this image appeared on V. Filippov's wall. Then a criminal case was initiated under Article 280 of the Criminal Code, which later the Article was changed to Article 20.3. Administrative Offences Code of the Russian Federation, and the citizen received an administrative fine for the promotion of Nazi symbols. The next example - in March 2014 historian K. Zharinov in the social net "VKontakte" chose an option "tell friend" under the post of "Right Sector", which said that "Russia's fate is determined in Ukraine, and now the Russians have the opportunity to fight against the "KGB Putin regime"; the "Right Sector" calls to organize mass protests, create guerrilla groups, block roads and destroy the military infrastructure. And immediately FSB (Federal Secret Service of Russia) initiated a lawsuit against the historian under Article 280 of the Criminal Code. The action was brought not only against K. Zharinov, but also 19-year-old student from Ivanovo E. Lisitsyna. And associate professor of Philosophy Faculty (Moscow State University) Viacheslav Dmitriev was detained by the FSB for his repost of an article about a possible change of government in Russia at the very Department of Ontology and Epistemology. A blogger from Kemerovo S. Kalinichenko is charged 
with retweeting a photo - again under article 280 of the Criminal Code. The photograph was taken on May 6, 2013 at Patriarch Ponds in Moscow and shows a leaflet with the text "Stop Going to Meetings and Start to Act!" signed by "The First Detachment of Fightback". See in detail: E.Mostovshchikov. There cannot be an erratic repost. Available at: https:// meduza.io/feature/2015/02/03/sluchaynogo-reposta-byt-ne-mozhet

22 Kalarsky District Court of Zabaykalsky Krai, for example, recognizes the following slogans as extremist (!): "A Russian chooses sport". Or, say: "Russian means sober". And even you would not believe it, the following slogan: "Glory to Russia!" Judicial Board on Civil Cases of the Zabaykalsky Krai Court takes an appeal against that decision and also recognizes the slogans as extremist. Or, say, the Central District Court of Novosibirsk at the request of the prosecutor of Novosibirsk Oblast found the slogan "Russian! Abstain!" extremist. See in detail: Maxim Kononenko. The fight against extremism in Russian: were there an article, and the person to punish would be found. Available at: http://radiovesti.ru/ episode/show/episode_id/24718

23 Sultanov, A. Extremism in Russian. Available at: http://www.gazeta-yurist.ru/article.php?i=1357

24 The federal law dated December 28, .2013 N 398-FZ "On amendments to the Federal Law 'On information, information technologies and protection of information". Collection of the legislation of the Russian Federation, 2013 N 52 (Part I). Art. 6963.

25 Let us recall that Russian "Daily Journal” (Ezhenedel'nyi zhurnal) together with Grani.ru and Kasparov.ru were the first victims of the so-called Lugovoi's amendments (to the Federal Law "On information, information technologies and protection of information"), which entered into force on February 1, 2014. The new law, initiated by a deputy from LDPR Andrei Lugovoi, allows Roskomnadzor on demand of Prosecutor General's Office making an immediate, without a court order blocking of websites calling to mass disorder and other extremist information. To unlock the site its owner should contact Roskomnadzor, as without its permission access to the site would not be renewed, even if the "extremist" materials have been removed from the site. On March, 13 Roskomnadzor blocked the media mentioned above due to the fact that, according to the organization, they "contain calls for illegal activity and participation in public events conducted in violation of the established order". Roskomnadzor has provided neither the owners of the resources, nor the court with the materials that were found to be extremist, and in spite of this these two courts upheld the Roskomnadzor's decision.

26 See in detail: http://minjust.ru/ru/extremist-materials?field_extremist_content_value=\&page=13\&search=

27 Report of the Prosecutor General of the Russian Federation on the state of the law and public order in the Russian Federation and on the work done to improve the situation in 2013. Available at: http:/genproc.gov.ru/smi/news/genproc/news$145698 /$

\title{
Конституционно-правовые проблемы
}

\section{антиэкстремистского законодательства в России: дефекты законодательной регламентации}

\author{
А.А. Кондрашев \\ Сибирский федеральный университет \\ Россия, 660041, Красноярск, пр. Свободный, 79
}

В статье дается критика доктринальных подходов к определению экстремизма, равно как и законодательной дефиниции экстремистской деятельности, выявлены пробель и противоречия законодательного регулирования ответственности за экстремистские преступления.

Ключевые слова: экстремизм, экстремистская деятельность, преступления на почве ненависти, нарушения конституционных прав и свобод граждан при применении антиэкстремистского законодательства.

Научная специальность: 12.00.00 - юридические науки. 